\title{
The intimate connexion
}

\section{Discovery of the metropolitan residuum}

Patrick Colquhoun, like the Fieldings, was a London magistrate. Having made a fortune as a young man in North America, and established himself as a leading figure among Glaswegian merchants, he migrated to London in 1792, where with the patronage of Henry Dundas he was appointed as the first stipendiary magistrate at the Finsbury Square Office. ${ }^{1}$ Utilitarianism mediated by Christian philanthropic sentiment and fears of the consequences of the French Revolution inspired him to write a variety of tracts on ale-houses, education and diets for the poor, the practical application of which was realized in the organization of soup kitchens to alleviate destitute silk weavers in Shoreditch, and in the promotion of the Society for Bettering the Condition and Increasing the Comforts of the Poor. In 1795 appeared the work for which Colquhoun is best remembered. A Treatise on the Police of the Metropolis has generally been regarded as laying the foundation for the establishment of the Marine Police Office at Wapping in 1798 and the Metropolitan Police in 1829. Arguably of greater historical significance, however, was its influence on perceptions of the poor, for in this and the subsequent $A$ Treatise on the Commerce and Police of the River Thames (1800) and $A$ Treatise on Indigence (1806) Colquhoun effectively redefined the poor as a predatory presence, organized in confederacies that operated within a moral economy to defend customary rights of access to moveable property. ${ }^{2}$

Using novel and sophisticated techniques of statistical inquiry, he estimated (often overestimated) the value of public and private property annually plundered in the metropolis:

1. Small Thefts $£ 710,000$

2. Thefts upon the Rivers and Quays 500,000

3. Thefts in the Dock-Yards, \&c. on the Thames 300,000

4. Burglaries, Highway-Robberies, \&c. 220,000 


\section{THE INTIMATE CONNEXION}

5. Coining base Money 200,000

6. Forging Bills, Swindling, \&c. 170,000

Total $22,100,000^{3}$

'This sum', Colquhoun added, 'will, no doubt, astonish the Reader, at first view; and may even go very far to stagger his belief; but when the vast extent of the trade and commerce of London is considered ... it will cease to be a matter of surprize, that under an incorrect system of police and deficient laws, the depredations are estimated so high.'

This classification was significant in a number of respects. A Treatise on the Police broke with the long tradition of perceiving the metropolitan poor as a bizarre collection of beggars and vagrants with criminal propensities. It did this by effectively remapping their moral, political and spatial boundaries. First, Colquhoun dismissed mendicity as a source of largescale criminal activity. His conception of criminal plunder was based exclusively on commerce and empire. He displaced elaborate taxonomies of petty street crime by conceptions of a criminal culture inscribed firmly within the sinews of capitalism and imperialism. Small theft was committed by 'servants, chimney-sweepers, dustmen, porters, apprentices, journeymen, stable boys, itinerant Jews, and others' from 'houses, shops, foundries, workshops, ... every other place where property is deposited'. More significant, however, was large-scale theft from riverside trade by various 'nautical Vagabonds' employed in the docks and on the river, or simply by those 'lurking about for plunder', which over time had reached levels 'to the great injury of the Community':

By degrees, probably ... little distinction was made in illicit transactions between the Adventure of the Individual, and the Property of the Merchant or Consignee of the Cargo.... The mind thus reconciled to the action, the offence screened by impunity, and apparently screened by custom, the habits of pillage increased: others seduced by the force of example, and stimulated by motives of avarice, soon pursued the same course of Criminality, while the want of apposite Laws, and the means of carrying into execution those that existed, gave an extensive range to Delinquency. New Converts to the System of Iniquity were rapidly made. The mass of Labourers on the River became gradually contaminated. - A similar class upon the Quays, and in the Warehouses, caught the infection, and the evil expanded as Commerce increased. ${ }^{4}$

This was not an exotic culture of finely delineated rogues, but an endemic, predatory and organized international underclass whose presence threatened the future of the nation. Over time, custom and practice, combined with the opportunity to pursue criminal activities without restraint, had perpetuated the evil. The establishment of the Marine Police Office had done much to eliminate these practices and reduce incidences of plunder. 
A more lasting solution, however, had to address the wider malaise not of poverty, but of indigence. Here Colquhoun reveals his debt to eighteenthcentury discourses around poverty and progress:

Poverty is ... a most necessary and indispensable ingredient in society, without which nations and communities could not exist in a state of civilization. It is the lot of man - it is the source of wealth, since without poverty there would be no labour, and without labour there could be no riches, no refinement, no comfort, and no benefit to those who may be possessed of wealth inasmuch as without a large proportion of poverty surplus labour could never be rendered productive in procuring either the conveniences or luxuries of life. Indigence, therefore, and not poverty, is the evil. ${ }^{5}$

The means must be found of preventing the poor from descending into indigence. Provision of the basic necessities is an urgent priority: 'There is no subject connected with political economy so difficult or important to the nation at large', Colquhoun argued, 'as the proper management of that branch of internal police which applies to those members of the body politic whose indigence exposed them to the miseries incident to the want of shelter, food, and clothing. ${ }^{6}$ Such want renders poverty 'worse in a state of civilization than in savage life'. Without this, the nation will continue to be afflicted by the criminal poor 'rendered noxious, offensive, and even dangerous, in consequence of depraved morals and criminal turpitude' ${ }^{7}$

Second, this underworld, created by commercial and imperial activity, was located not in the City or Westminster but in the riverside areas of East London. Colquhoun effectively 'discovered' the casual residuum, simultaneously opening up East London to inquiry as the centre of gravity shifted to the dockland areas of Wapping and Limehouse. His endeavours, backed financially by the West India Merchants Committee, were initially directed to the establishment of Marine Police Station at Wapping, some thirty years before the Metropolitan Police force was eventually formed. In attempting to reveal this area of criminal activity, however, Colquhoun effectively criminalized large parts of the East End by linking casual labourers in the docks to an extensive and highly organized network of receivers and dealers in stolen property. Sugar, for example, was disposed of as follows:

There are several Public Houses in the neighbourhood of Thames-street, to which the Journeymen Coopers resort with their Boards of Sugar. - In these receptacles a kind of market is held, where the small Grocers attend, and by means of fictitious Bills of Parcels cover the stolen Property to their respective houses.... The parties who form this criminal confederacy, are said to be great adepts in eluding Justice. - They have established a principle with regard to judicial oaths, affecting the security or tending to the acquittal of their companions in iniquity. ${ }^{8}$ 


\section{THE INTIMATE CONNEXION}

Concern was heightened by the belief that this criminal underworld was organized. Although fears had occasionally surfaced in the eighteenth century that itinerant vagrants roamed the countryside in gangs, few believed metropolitan beggars and thieves formed themselves into confederacies. For the most part such crime was seen to be petty and individualistic. ${ }^{9}$ River plunder, on the other hand, was a complex operation that depended for its success upon cooperation. Colquhoun estimated, for example, that each day more than ten hundredweight of sugar was taken from West India ships by lumpers and their associates:

These aquatic labourers are for the most part in connection with the journeymen Coopers and Watermen, who are supposed to share in the plunder. They generally go on shore three times a day, and being in a body together, it is difficult, and sometimes not very safe, for a Trinity or Police Officer to attempt to search or to secure even one of them. ${ }^{10}$

Third, Colquhoun revealed this underworld through rational inquiry. His use of detailed statistics and reports was from the outset recognized as a departure:

$[\mathrm{T}]$ he author has submitted to the consideration of the reader, a variety of evils of great magnitude, with other specific details; which are not to be found in books, and which, of course, have never been laid before the public through the medium of the press. It may naturally be expected that such an accumulation of delinquency, systematically detailed, and placed in so prominent a point of view, must excite a considerable degree of astonishment in the minds of those readers who have not been familiar with subjects of this nature. ${ }^{11}$

This found an audience among a reading public anxious to know better the complex totality of social and spatial relationships in the metropolis. History tends to remember Colquhoun as the founding spirit of the Metropolitan Police, but his influence on nineteenth-century discourses of poverty and crime was of equal significance. Frequent references were made to his data in the writings of evangelicals and urban travellers. More obliquely, the trope of the casual residuum, concentrated in the East End, was to frame much of the thinking on the spatiality of poverty for the remainder of the century.

Not that concern around begging and vagrancy entirely evaporated. At the close of the Napoleonic Wars, when beggars seemed again to swarm the streets of London, the government appointed committees of inquiry into the state of mendicity and vagrancy (1815) and the state of the police (1816) in the metropolis. Much of the evidence submitted on the extent of mendicity, recommendations for its suppression, and the effectiveness of the law and its officers, was so contradictory that it was virtually impossi- 


\section{THE OTHER EMPIRE}

ble to build a coherent and reliable picture. What did emerge, however, was a sense of the extent to which beggars continued effectively to order space. William Gurney, minister of the Free Chapel, St Giles, spoke of beggars' ability to claim walks as a 'sort of property' - a claim made possible by the 'humanity of the population; people cannot bear to pass by distress without relieving it'. ${ }^{12}$ And Sampson Stephenson, iron founder in Seven Dials, described the ways in which groups of beggars quartered the town into sections and divisions, 'and they go one part one way, another part another'. ${ }^{13}$

\section{Gothic heaps of stone}

Colquhoun thus 'discovered' the casual residuum in East London, and to an extent East London itself. As London developed to the east, its manufacturing centre of gravity shifted from the older areas of silk weaving in Whitechapel and Spitalfields to the dockland areas of Wapping and Limehouse. And yet East London remained little known. In 1783 J. Ralph surveyed London. Noting the 'celebrity of the Metropolis of the British Empire, and that natural wish which the intelligent among its inhabitants must have to be acquainted with the remarkable things it contains', he began by exploring the built environment of its 'remotest extremity':

As there were no attempts, till lately, ever made to erect any building which might adorn it at all, there was the more necessity to be particularly careful that the first design of this nature should not miscarry; and yet the four churches which have been built at Limehouse, Ratcliffe, Horsleydown, and Spital Fields, though they all have the advantage of ground which can be desired, are not to be looked at without displeasure. They are merely Gothic heaps of stone without form or order, and meet with the contempt from the best and worst tastes alike. ${ }^{14}$

Colquhoun developed this anthropomorphism precisely by elaborating the 'form and order' of these 'Gothic heaps of stone'. Property plundered in the metropolis was classified in ways that would have been familiar to Fielding. The values lost through small thefts committed by 'servants, chimney-sweepers, dustmen, porters, apprentices, journeymen, stable boys, itinerant Jews, and others', burglaries, highway robberies, counterfeiting and forgery were all estimated. But the real object of concern was riverside plunder. Thefts upon the river and quays, and in the dockyards of East London, were subjected to detailed statistical inquiry, as a result of which casual labourers, concentrated around the riverside areas, and the large variety of dealers in the vicinity supported by their activities came to be identified as the new criminal underworld. The theoretical status of this residuum was consolidated by classifications of poverty. Colquhoun's 
delineation of the poor into the useful, vagrant, indigent, aged and infirm, and infant was hardly original, but he conferred on it a dynamic sense of change. Boundaries were recognized to be mobile; under particular circumstances, the useful poor, for example, could descend into the indigent poor to be relieved through public funds, or into the vagrant poor to be the peculiar object of the 'national police'.

The metropolitan poor were thus reconstituted as an international and criminalized underclass at the vortex of commercial and imperial endeavour. Colquhoun acted for and articulated the interests of a mercantile elite who not only initiated the investigation of river plunder but also subsequently financed the Marine Police Office at Wapping. He had the ear of those West India merchants and politicians who had played a prominent role in establishing the Atlantic system and who at a time of political and economic uncertainty now felt threatened by the unfettered activities of their labour forces.

It would be mistaken, however, to view figures like Colquhoun solely as zealous persecutors of the poor. His avowed aim was to prevent rather than punish criminal propensities by leading the poor into 'the paths of honest industry'. For those unable to work, adequate provision had to be made through the 'benevolence of the Publick', equalization of rates, soup kitchens, savings banks, and reform of the poor laws. As the political crisis passed, and the Marine Police Office survived ${ }^{15}$ (to the evident satisfaction of the West India merchants, who witnessed a dramatic fall in losses and with renewed confidence embarked on plans to build the West India docks), so Colquhoun continued to campaign for a metropolitan-wide police force, wrote books on the problems of redundant labour and immersed himself in charitable pursuits. In this he confronted and revealed some of the complexities in contemporary thinking about metropolitan poverty, for Colquhoun moved in evangelical, utilitarian and legal circles, and evidently saw no incongruity in so doing.

The Society for Bettering the Condition and Increasing the Comforts of the Poor was founded in 1796 by a group of evangelicals under the leadership of Sir Thomas Bernard. Bernard had a history of involvement in the humanitarian campaigns of Jonas Hanway, and with the help of Wilberforce was able to recruit a highly influential committee that included the king as patron, bishops, MPs and Colquhoun. ${ }^{16}$ Although based in London, the Society had a national focus, evidenced in the undue attention given in its reports to the administration of the poor law. In its 1799 report Information for Overseers, a spinning school, a parish windmill, stewed ox head and whitewash were offered as advice. ${ }^{17}$ These could hardly be construed as solutions to metropolitan problems. And yet we can detect in the reports a faltering elaboration of an evangelical moral and practical universe that was to have a profound impact on the metropolis 


\section{THE OTHER EMPIRE}

for much of the nineteenth century. The overarching ethos was of a passionate moral paternalism rather than material paternalism. ${ }^{18}$ Public relief and rigorous discipline of the poor were discouraged; instead 'that master spring of action, on which equally depends the prosperity of individuals and empires - THE DESIRE IMPLANTED IN THE HUMAN BREAST OF BETTERING ITS CONDITION' was raised as the guiding principle to action. ${ }^{19}$ Moral regeneration of the poor through self-help, industry, frugality, purity and the suppression of vice was the ideal to be pursued.

All this was predicated on an unabashed empiricism. Information on the education, health and general condition of the poor, together with successful schemes of improvement, was sought from a large variety of sources and then repackaged and disseminated widely as the practical basis to action. Significantly, in the metropolitan context mendicity attracted the attention of the Society. On the instigation of Bernard, and with the support of the government under the sanction of Lords Pelham and Portland, Matthew Martin undertook in 1796 an inquiry into London beggars. ${ }^{20}$ Two thousand cases were examined by Martin and his assistants. But the task proved overwhelming. Six years later he was forced to write an open letter to Pelham expressing regret for failing to produce the report:

$[T]$ he complicated nature and extent of the misery, which has been the subject of my research, and the consequent difficulties which ... I have encountered in my endeavours to reduce my observations to such a form, as to explain the matter with a suitable degree of perspicacity and force, may, I hope, plead my excuse. ${ }^{21}$

In spite of this perceived failure, the statistical data on the metropolitan poor were significant. Whereas Colquhoun had produced impressive tables to strengthen his arguments, much of his information was based on estimates, some of them wildly exaggerated. Martin's figures, however, were the first to be gathered using recognizably modern techniques of surveying, and it is retrospectively perhaps of little surprise that he was defeated by the sheer unknowability of the problem they uncovered.

Others in the movement were beginning to appreciate the importance of obtaining first-hand knowledge of the poor. In 1799 John Venn established a local branch of the Society for Bettering the Condition of the Poor in Clapham. The parish was divided into eight districts where the poor were regularly visited..$^{22}$ And in 1812 , against a backdrop of unremitting and widespread destitution amongst silk weavers, the Association for the Relief of the Industrious Poor of Spitalfields and its Neighbourhood was established. The inspiration was the evangelical and former overseer Thomas Buxton, who later claimed in a speech made at the Egyptian Hall in 


\section{THE INTIMATE CONNEXION}

1816 that the association was necessary because 'private charity found itself perplexed, confused and baffled by the variety of applicants, and hardly knew which was right, the partiality which would elect some, to the exclusion of others - or that impartiality which would give but a crumb to each'.$^{23}$ Over a hundred volunteers helped to undertake a survey during which every street was visited regularly. The system was immediately recognized to have distinct advantages for 'the poor are seen at their own houses, the truth of their tale is ascertained; we are not so much exposed to deception'. In the eleven weeks preceding November 1816, 8,460 visits were made. Buxton paid generous tribute to Colquhoun for his role in bringing the plight of Spitalfields to the attention of the Privy Council: 'The unwearied exertions that this indefatigable magistrate persevered in ... can only be sufficiently appreciated by those to whom they are fully known:- his name will long be revered by many in this parish, and when they cease to respect it, they will cease to exist'. ${ }^{24}$

Concern about poverty and crime intensified toward the end of the Napoleonic Wars when thousands of demobilized soldiers and sailors were reduced to begging on the streets of London. The select committees established to investigate mendicity and vagrancy (1815) and the state of policing in the metropolis (1816) reflected both renewed anxiety and the continued failure to grasp fully the complexities of the problems. The evidence taken before the Committee on Mendicity were republished commercially in the

hope of drawing attention of the public to a subject, involving considerations of the highest importance to the community, from its connection with the morals and the welfare of the lowest classes in society. Mendicity, wherever it prevails, and in proportion to its extent, is a great evil, which calls for the most serious attention of the legislative and executive powers. ${ }^{25}$

Among the variety of magistrates, reformers, police and poor law officials who appeared there was little agreement on the extent of mendicity, its causes or potential solutions. Faced with this, the Committee confessed it could not 'refrain from a smile on perusing some of the evidence', in particular the conundrums of Conant and the metaphysical distinctions of Colquhoun', and declined to 'express any opinion as to the measures it may be fit for Parliament to adopt' ${ }^{26}$ The Police Committee was no more successful. The evidence submitted on crime and the enforcement of law was replete with contradiction, and the Committee for the most part seemed content to record caustic comments on it. No recommendations were forthcoming.

From the close of the eighteenth century, therefore, the metropolitan poor were viewed with heightened concern as a threat to commercial and imperial interests. At the moment when London emerged as a great centre 
of world trade, empire, law and government, built upon an extensive Atlantic system and with an avowed determination to exploit massively its links with the East, here was a constituency located at the very core which presented a barrier to progress. For the poor defied these modernizing impulses. They remained on the streets, effectively resistant to all attempts to cleanse and hence secure sites of bourgeois public space. And as a picaresque and international residuum drawn in increasing numbers to dock and riverside areas, they were a canker at the heart of commercial prosperity.

\section{Late eighteenth-century travel in India}

If a unitary field was created between metropolis and India it was not done so instantaneously. The emergence of significant bodies of knowledge in the late eighteenth century followed a period of relative inactivity when little new was learnt about the diversity of either metropolitan culture or that of native Indians. Even during the climate of enthusiasm for information, however, we must be cautious in identifying putative links. The investigative modalities instigated by the East India Company, for example, were no doubt driven by rational impulses of an Enlightenment epistemology, but their aims were distinctive. Three projects stood out. ${ }^{27}$ William Jones sought to codify the Indian legal system, and in so doing 'discovered' India's ancient past; Thomas Munro laid the foundations for the administration of land settlements; and James Rennell mapped India. Although each relied on knowledges and methodologies that had been developed in the West, there was no obvious reference to metropolitan concerns. Thus Rennell's Memoir of a Map of Hindustan may have first appeared in the aftermath of the detailed mapping of London by cartographers such as John Rocque and John Entick, and may have expressed the same desire to gain authority over unknown space, but the outcome was very different. Neither topographical maps of London nor Ordnance surveys contributed to the project of mapping India. ${ }^{28}$

Attempts to locate India historically similarly drew upon implicit understandings and served to consolidate Company administration. Alexander Dow's History of Hindostan (1768) and Robert Orme's A History of the Military Transactions of the British Nation in Indostan (1763) inhabited teleological narratives celebrating the advantages of British rule, particularly over the tyranny of the Mughal empire. Neither contributed to contemporary knowledge of India. More significant was William Robertson's An Historical Disquisition concerning the Knowledge which the Ancients had of India (1791). This was a serious study, written by a noted historian ${ }^{29}$ who, although he had never visited India, was familiar with the latest work: 


\section{THE INTIMATE CONNEXION}

Major Rennell's Memoir for illustrating his Map of Indostan ... suggested to me the idea of examining ... into the knowledge which the ancients had of India, and of considering what is certain, what is obscure, and what is fabulous, in the accounts of that country which they have handed down to us.... I have consulted with persevering industry, the works of all the authors I could procure, who have given an account of India. ${ }^{30}$

Robertson, like Jones upon whom he relied for much of his knowledge of Indian literature, admired much in ancient Indian culture. '[T]he wisdom of the East (an expression which is to be understood as a description of their extraordinary progress in science and arts)', he claimed, was early celebrated by the inspired 'ancient Heathen writers' ${ }^{31}$ In the modern age, however, European thought had surpassed the ancients. 'Proud in their superior attainments', but with 'proper sentiments concerning the people of India', Europeans now had a moral duty to bring Indians to the same level of civilization. ${ }^{32}$

Important though this body of work was in framing British responses to India in the late eighteenth century, it remained the province of elites in terms not only of the object of inquiry but also of the inquirers and audience. The culture described was that of the Brahmin intellectual and religious elite; no attempt was made to understand popular Hinduism or Indian culture more widely. ${ }^{33}$ And although works such as Dow's sold well, most reached few readers beyond Company functionaries and interested middle-class observers of Indian affairs. The reading public turned to travel narratives.

We have already examined the contribution of travel writings to the early knowledge of India. The growing body of recent scholarly work on the genre suggests strongly that in the modern colonial era this contribution showed no signs of diminishing. ${ }^{34}$ Travel and travel writing were deeply implicated in Western modernity. The earlier displacement of a Christian cosmography by secularized frames of reference was further developed in the post-Enlightenment era by a more sophisticated geographical and ethnological consciousness. Complex taxonomies of colonial spaces emerged that facilitated differentiation not only among, say, Europe, India, America and Africa, but also regions with distinct topographies and cultures. ${ }^{35}$ Thus were promoted influential currents of thought around primitivism and orientalism that both problematized and provided mythical solutions to questions about the right path to civilization. ${ }^{36}$ Unsurprisingly, the European emerged as triumphant.

In a comprehensive literary survey of British travel writings on India, Ketaki Dyson has pointed to similar currents. Accounts were erratic, diverse and inconsistent but in broad terms can be understood only in the context of intellectual concerns. Eighteenth-century attitudes toward India, therefore, were broadly shaped by Enlightenment thought. ${ }^{37}$ As the 
century closed, this outlook was displaced increasingly by evangelicalism and a radical utilitarianism, in the course of which the sympathetic conservatism of orientalism yielded to a more aggressive project intent on dragging India into the civilized and modern world. This shift was accompanied by changes in the modes of literary expression as an eighteenthcentury sensibility was gradually superseded by Romanticism..$^{38}$

The renewed interest in travel accounts attendant upon Britain's colonization of India in the latter half of the eighteenth century displays a faltering struggle to comprehend its land and peoples. The artist William Hodges was an accomplished traveller by the time he reached India in 1780. He had previously painted scenes of Europe, and, as a draughtsman on Cook's second voyage, produced a series on New Zealand. Under the patronage of Warren Hastings, his journey to India aimed to record initial impressions in a series of drawings as a means of providing information on aspects neglected by orientalists:

The intimate connexion which has so long subsisted between this country and the continent of India, naturally renders every Englishman deeply interested in all that relates to a quarter of the globe which has been the theatre of scenes highly important to his country.... It is only a matter of surprize, that, of a country so nearly allied to us, so little should be known. The public is, indeed, greatly indebted to the learned labours of gentlemen who have resided there, for the information which they have afforded concerning the Laws and the Religion of the Hindoo tribes; as well as for correct and well digested details of the transactions of the Mogul government. But of the face of the country, of its art, and natural productions, little has been said. ${ }^{39}$

Hodges's artistic imagination responds with unalloyed wonder and pleasure to the novel sights he encounters but reveals little beyond the immediate sense of the visual. Using classical referents to make sense of his first sight of India, he contemplates that the English settlement at Madras resembled a Grecian city at the time of Alexander:

The clear, blue, cloudless sky, the polished white buildings, the bright sandy beach, and the dark green sea, present a combination totally new to the eye of an Englishman, just arrived from London, who, accustomed to the sight of rolling masses of clouds floating in a damp atmosphere, cannot but contemplate the difference with delight. ${ }^{40}$

In an act that became of singular importance to the appropriation of the remote in the late eighteenth century, ${ }^{41}$ landscapes and people were also seen primarily in visual terms. Such sights as travelling family groups or Muslim women attending the tombs of relatives at night are described as picturesque, while the flat landscape by the expansive Ganges provides a sublime prospect of 'inexpressible grandeur'. Other landscapes are compared to England. 


\section{THE INTIMATE CONNEXION}

The hard-headed George Forster, a clerk in the employ of the East India Company, viewed such narratives with a degree of scepticism. 'Travellers stand accused', he stated, 'of adopting a figurative and loose style of description. ${ }^{\prime 42}$ His journey may include places 'removed from the eye of European observation', but he could reassure the public that the work 'has no tendency to discolour or misrepresent truth'. Relying on disguise and a fluency in the 'Mahometan language', Forster travelled widely. His observations on diverse aspects of Indian culture augmented a linguistic repertoire that was to become familiar. Hindus were of an 'inert disposition', facilitating the rise to power of inept rulers, often with ruinous consequences. And Kashmiris were dismissed as a body of men 'impregnated with the principles of vice'. It would be wrong, however, to view Forster as a crude racial caricaturist; his assessments were replete with ambiguity. Indian women, for example, no matter how uneducated and subordinated in a patriarchal society, possessed extraordinary vocal imagination and stamina:

In the exercise of the tongue a female of Hindostan hath few equals; and if she hath ever followed a camp, I would pronounce her invincible on any ground in Europe. An English woman, educated at our most noted seminaries, and skilled in all the various compasses of debate, will, perhaps, ... maintain the contest for an hour, which then terminates in blows and victory. But an Indian dame, improved by a few campaigns, has been known to wage a colloquial war, without introducing one manual effort, for the space of three successive days; sleeping and eating at reasonable intervals. There is a fertility of imagination, a power of expression, inherent in the mind, and vocal ability, of an Asiatic, particularly a female one, which cannot be engendered in the cold head of an European. ${ }^{43}$

Forster was also interested in the Sikhs, whose nascent political presence and distinctiveness were registered in the British imagination for the first time. He begins by describing their warlike character. This 'new and extraordinary people' are a

turbulent people, and possess a haughtiness of deportment which ... peculiarly marks their character.... From the spirit of independence so invariably infused amongst them, their mutual jealousy, and a rapacious roving temper, the Sicques at this day are seldom seen cooperating in national concert. ${ }^{44}$

But then in a remarkable passage he proceeds to predict the rise of Sikh power under Ranjit Singh:

Should any future cause call forth the combined efforts of the Sicques to maintain the existence of empire and religion, we may see some ambitious chief led on by his genius and success, and, absorbing the power of his associates, display, from the ruins of their commonwealth, the standard of 


\section{THE OTHER EMPIRE}

monarchy... Under such a form of government, I have little hesitation in saying that the Sicques would be soon advanced to the first rank amongst the native princes of Hindostan; and would become a terror to the surrounding states. ${ }^{45}$

From the earliest years of the revival in travel writings on India women authors were prominent. As wives of Company functionaries and army officers many women played subsidiary roles in the business of empire. Endless days of boredom could be relieved by recording observations on their lives in India, published details of which found a ready audience in Britain. As such these travel writings can be situated within a longer tradition of autobiographical self-expression, particularly in the form of diaries. The more vexed question is whether or not there was a distinctly female mode of observation. Dyson claims that women were directed to distinct objects of inquiry. Because they had little access to the male preserves of administration, orientalist research and sport, women's journals were rich sources of information on Indian domestic life, rituals, fashion and food. ${ }^{46}$ The contrasts, however, can be overstated. Many of the women were intrepid travellers who proved themselves capable of reaching the remotest regions of Indian topography and culture. In the case of the zenana - a subject of particular fascination to the British reading public - they had privileged access. And they were intensely curious about mythology, folklore and custom. Importantly, even if we can detect a gendered object of inquiry, it is difficult to support the argument that it was seen differently by women. 'There is no specifically female gaze', concludes Indira Ghose in her comprehensive survey of female travel writings on India, 'for the simple reason that gender is only one of a multiplicity of factors that determine identity. ${ }^{\prime 47}$

Jemima Kindersley was married to an officer in the Bengal Artillery. She arrived in India in 1765 and stayed with him for four years. Her reaction to the first sighting of Indians reveals an outlook inflected more by race and class than gender:

the first specimen I had of India rather surprised than pleased me; I could not be reconciled to the vast numbers of black people who flocked to the shore on my first arrival; although I must acknowledge, that they were so far from being terrible in their appearance, that at first sight I believed them all to be women, from the effeminacy both of their persons and dress, the long white jemmers and turbands appear so truly feminine to strangers. But the almost stark-nakedness of the lowest class is still more disgusting. ${ }^{48}$

Blackness and nakedness were familiar signifiers of otherness, but it would be incautious to interpret them as evidence of a blatant racial discourse. Elsewhere Mrs Kindersley resisted the thesis that black people were 'by nature inferior to white' ${ }^{49}$ Instead, inhabiting an Enlightenment 
sensibility heavily influenced by Montesquieu, she attributes Indians' indolence, stupidity and lack of development to climate, superstition and despotism:

[I]n the cold season they have a fire made with a little straw in the middle of their huts, which smothers them with smoak; their minds, except what nature gave them, no more informed than the beasts which perish: no liberty, no property, subject to the tyranny of every superior. But what seems to complete their misery is, that whether pinched by cold, or enervated by heat, indolence equally prevails, to such a degree as seems to absorb every faculty; even immediate self-preservation scarcely rouses them from it..$^{50}$

The strength and energy of some Indian labourers suggested that indolence was not a physical problem: 'although the climate is certainly extremely relaxing, it seems to impair their minds more than their bodies; to which indolence of spirit, a despotical government and its consequences has perhaps not a little contributed' ${ }^{.51}$

Early in the nineteenth century Captain Thomas Williamson, a resident of more than twenty years in Bengal, felt confident enough to write a compendium of useful information 'to promote the welfare, and to facilitate the progress of those young gentlemen who may ... be appointed to situations' in the East Indian Company. ${ }^{52} \mathrm{He}$ drew upon the state of contemporary knowledge. Among works cited are Brooke's Gazetteer, Dow's History of Hindostan, Fuller's Apology for late Christian Missions to India, Tennant's Indian Recreations, Lauderdale's Government of India, Orme's History of the Military Transactions, Robertson's Disquisitions on Ancient India and Wellesley's History of the Mahratta War. Books recommended for the traveller, on the other hand, are mostly on language and law, and include studies by notable orientalists such as Wilkins, Colebrooke and Jones. The East India Vade-Mecum was, however, more than simply a guide - it simultaneously aimed to promote a 'just conception of the characters of the natives', so removing those 'doubts, prejudices, and national opinions, which, if suffered to prevail, must occasion every object to be seen through a false medium'. In over a thousand pages of unbroken prose, Williamson provides instruction on a bewildering variety of topics from travel to India, coins and weights, classifications of servants, vaccination, heat, salt manufacture and slavery to dress, ornaments, snakes and styles of buildings.

The lengthiest section is devoted to servants. In a style redolent of eighteenth-century vade-mecums on the metropolis, Williamson details the histories, responsibilities and propensities of Indians whom the European is likely to encounter. Moonshies (linguists), for example, are 'generally influenced by motives wide from purity.... With very few exceptions, we find them extremely debauched, and unhealthy. With what venary, 


\section{THE OTHER EMPIRE}

drinking, smoking, \&c. nine out of ten of them exhale the most intolerable effluvia!'53 The Sircar (book keeper) is a

Genius whose whole study is to handle money ... and who contrives either to confuse acounts ... or to render them most expressively intelligible when such should suit his purpose. These rogues are pretty near the same as the Madras debashes: no compleater knaves are to be found in any part of the world. ${ }^{54}$

This seemingly exaggerated interest in servants was symptomatic of the general sense of unease felt by members of the eighteenth-century bourgeoisie. Servants transgressed the boundaries between the public and private space. They had access to possessions and, more importantly, information, as a result of which they were considered a threat, or at best treated with suspicion. In the colonial context, as Kate Teltscher has reminded us, this threat was intensified. ${ }^{55}$ Servants outnumbered their masters, and as part of a wider network were able to subvert political, financial and cultural relationships. Deference and subservience could always be read as acts to disguise defiance. And yet Williamson refuses to accuse the 'natives of India' of being

so debased, so immoral, or so vindictive, as they have been represented by many gentlemen, especially some divines who have lately returned from the East, and whose opinions breathe by no means the spirit of that sublime religion they would coerce the natives to adopt.... I think we have by far more to admire than to censure, in a race of people, who, notwithstanding some highly remarkable instances of depravity, may be classed among the most innocent, and most industrious, of worldly inhabitants!!!56

The reference here to a harsher discourse on colonial subjects is significant, for by the turn of the century it was apparent that missionaries, particularly evangelicals, were beginning to intervene in the production of knowledge about India. Over time this intervention was to be of critical importance to the ways in which British people saw Indian people and culture.

\section{Early evangelical activity}

Missionary activity in India was transformed in the course of the eighteenth century. For the first seventy years French and Portuguese Jesuits continued to dominate the scene, and it was largely through their published accounts that the European imagination of India was formed. Lettres Edifiantes et Curieuses, for example, appeared in thirty-four volumes during 1702-76, effectively eclipsing secular narratives while displaying few of their uncertainties in representing Indian culture. ${ }^{57} \mathrm{~A}$ 


\section{THE INTIMATE CONNEXION}

Danish Lutheran mission was established at Tranquebar in 1706. It was later adopted and partly financed by the Society for Promoting Christian Knowledge (SPCK), but remained small. British Protestant missionary activity in India can realistically be dated to the last decade of the eighteenth century. In 1792 the Particular-Baptist Society for Propagating the Gospel Among the Heathen (happily soon to be changed to the Baptist Missionary Society, BMS) was established, and within a year despatched William Carey to set up the first of its missions at Serampur. Three years later the interdenominational London Mission Society (LMS) was formed, followed in 1799 by the Church Missionary Society (CMS), largely under the inspiration of Anglicans who had broken adrift from the LMS.

Much scholarly work has been devoted to an explanation of this sudden rise in British missionary endeavour. ${ }^{58}$ One broad camp links it to the simultaneous expansion of the British imperial state. According to this perspective, missionaries were agents in the spread of colonial power, not least as bearers of its underpinning values. The second views it as the product of profound theological changes in the eighteenth century. British evangelicalism first emerged in a domestic context; the development of its mission work overseas was integral to the project of spreading the word of Christ around the world, and operated independently of the pursuit of imperial ambitions. I cannot here adjudicate between these positions - to propose, as Susan Thorne has, ${ }^{59}$ a synthesis, or to raise, as Andrew Porter has, the divergence between religious and imperial needs ${ }^{60}-$ but it is necessary to examine some of the complex specificities of evangelicalism in India.

The spatial and temporal dimensions of missionary endeavour in the subcontinent were critical. The opening up of India after Plassey provided opportunities for missionaries as well as imperial entrepreneurs. The first mission was located at Serampur within easy reach of Calcutta. Only later did missionaries venture out into territories beyond the reach of the British Raj. And in certain important respects the moment was tied to imperial expansion. The transformation in missionary activity signalled first in the Caribbean and then in India has to be linked to the transition from the first to the second British empires at the end of the eighteenth century. ${ }^{61}$ During this period the emphasis of colonial policy turned from securing British settlement to the governance of indigenous populations. When John Wesley and George Whitfield established evangelical missions in America it was to help remove the threat posed by the native Indian population. In India, missions were much more determinedly committed to the large-scale conversion of the indigenous population, and even if this civilizing mission was not always thought in terms of the maintenance of political and cultural authority, in practice that was how it tended to operate. 
This transformation was impelled also by conceptions of progress that emerged toward the close of the eighteenth century. Two aspects in particular were significant. Missionary activity abroad in part represented a new vision of work among the dispossessed. Eighteenth-century philanthropy and the poor law had emphasized secular, material provision as a means of ameliorating distress and meeting the demands for productive labour. As critiques of poor relief and philanthropy mounted, ${ }^{62}$ and as the demographic crisis eased, so attention turned to spiritual improvement. Evangelicals, preoccupied as they were by conversion and atonement, were eminently qualified to take up the cause. This shift from humanitarian to missionary philanthropy affected attitudes to the poor, but simultaneously directed attention to peoples colonized by the (re)orientation of Britain's imperial endeavours. Thus, although missionary activity was rarely blind to the material deprivations suffered by Indians, its emphasis was almost exclusively on the saving of their souls as a precondition of bringing them into the civilized world. And this promoted harsher and more rigid categorizations of the colonized..$^{63}$

The first wave of missionary activity in India came at a time when expressions of the need for evangelization of its peoples were being voiced with increased concern. Under the rubric 'Go ye into all the world, and preach the gospel to every creature' (Mark XVI 15), Joseph White, Professor of Arabic at Oxford, preached before the university in 1784 on the duty of promoting the universal and progressive message of Christianity 'among our Mahometan and Gentoo Subjects in India'. ${ }^{64}$ The decisive intervention, however, was made by Charles Grant. Grant travelled to India in 1768 as a private agent to Richard Beecher, a prominent servant of the East India Company. ${ }^{65}$ Over time Grant established himself variously as a founder member of the Clapham Sect, a Director of the East India Company, a Member of Parliament, and until his death in 1823 the dominant voice on Indian affairs. His first years, however, were hardly auspicious. Like so many of his contemporaries, he gambled heavily and lived beyond his means, running up a debt of $£ 20,000$. These losses were compounded by the death from smallpox of his two children, convincing Grant that he had been singled out by God. He underwent a conversion of sorts, after which he lived a virtuous and hard-working life in pursuit of what he considered the best interests of the Company and the Indian people. ${ }^{66}$

Grant transformed attitudes to Company rule. In contrast to criticism of the Company launched by Adam Smith in the aftermath of the devastating Bengal famine of 1770, Grant had argued that the directors did all in their power to prevent suffering. By the time of Warren Hastings, Grant's opinion of Company rule had hardened. He blamed Hastings for a war of aggression against the Marathas which was not only unnecessary 


\section{THE INTIMATE CONNEXION}

but threatened the security and prosperity of Bengal. During the subsequent impeachment proceedings he resisted a public demonstration of support for either side, and while continuing to defend the Company from undue state interference, recognized the merits of the 1784 India Act, seeing it as the culmination of reforms already set in motion by Company servants ${ }^{67}$ Increasingly, however, Grant was persuaded that moral reform in India was a precondition of political reform. In a letter to Thomas Raikes soon after the 1784 Act entered onto the statute book, he argued that although

inquiries into the evils that afflict the people and the means of addressing them are now deservedly become a business of Government, yet I shall fear that all remedies will prove ineffectual which have no respect to the moral and intellectual state of the inhabitants.... I am not, as you may believe, for following the Mahomedan example of establishing opinions by the sword; but I certainly am for helping those poor people whose land we enjoy, who are now in effect subjects of Britain, to recover the almost lost life of nature, and to become acquainted with the truth and excellence of Revelation, with the improvements and the rights of man. ${ }^{68}$

By now Grant was beginning to think seriously about effective missionary work in India. A plan for an Indian mission had been communicated to him by Thomas Coke in 1783, and four years later Grant expressed his first thoughts in a paper entitled 'A Proposal for Establishing a Protestant Mission in Bengal and Behar', fourteen copies of which were distributed to influential contacts. ${ }^{69}$ In the event it aroused only limited support in Anglican circles. We can detect in the Proposal, however, the elements of Grant's thoughts on the relationship between imperial administration and missionary endeavour that were to exercise such a significant influence on the establishment of the CMS and the agenda of subsequent debates. He begins by pointing out the neglect of such vital matters. 'Among all advantages accruing to Great Britain from the acquisition of Asiatic Territories', he argued, 'the power of introducing the Light of Truth among them, of making known to them the way of Everlasting Life, and the true source of source of temporal happiness, has hardly been mentioned.' It is evident, however, that in spite of Grant's interest in the spiritual welfare of Indians, the exigencies of rule were never far from his thoughts:

$[T]$ he People of these Provinces in their present state are far from being easily governed, if that term means any thing more than keeping them from Insurrection and Revolt... [They] are universally and wholly corrupt, they are as depraved as they are blind, and as wretched as they are depraved, and to govern them and render them obedient and orderly upon right principles, is no easy Work. There has been much inquiry concerning the best system of managing the Country. It seems to us clear that no system which has not the Reformation of the morals of the People for its basis can be effective; for they 


\section{THE OTHER EMPIRE}

are lamentably destitute of those Principles of Honesty, Truth, and Justice which are necessary for the Well-being of Society. And to reconcile them to Foreign dominion like Ours, it seems equally clear that We and they ought to have some strong common Principles; at present they are united to us neither in Interest nor in Sentiment. ${ }^{70}$

The Proposal galvanized the support of Charles Simeon and William Wilberforce. Politicians and established churchmen, on the other hand, were less than enthusiastic. Pitt and Cornwallis, while not opposing missionary schemes, had no faith that they could be effective. ${ }^{71}$ Without this support Grant's plan for government patronage of missionary work in India failed. Determined to learn from this lesson, he took the first propitious opportunity to elaborate on his thesis, this time for a political audience. Thus the initial draft of Observations on the State of Society among the Asiatic Subjects of Great Britain was addressed to Henry Dundas. It appeared during negotiations for the renewal of the Company's charter in 1792, and was intended to provide the basis for government policy. The negotiations for the renewal of the Company's charter provided a propitious moment. Over time and in its various manifestations the work was to become arguably the single most influential tract on missionary work in India. ${ }^{72}$

Observations is a hymn to the spiritual and rational progress of India, written at a time when its edifice seemed under threat from revolutionary currents. Indeed, so sensitive was Grant to these currents that he felt impelled from the outset to distance the novelty of his proposals:

At a time when the wildest fanaticism in politics and philosophy is pursuing, with impious and inhuman success, the indiscriminate subversions of received principles and existing establishments, labours under peculiar disadvantages. Truth however, and reason, always the same, are not to be abandoned because they may sometimes be perverted and abused. ${ }^{73}$

His aim is 'to promote the peace and happiness of men, by pacific and rational means'. What precisely did this mean in the context of India? To answer this Grant reviews the recent history of British intervention. Although the Company has had success 'which the commercial history of the world affords no parallel', and demonstrated a 'laudable zeal for extending ... the knowledge of the Gospel to the Pagan tribes', it has neglected the welfare of 'our Asiatic subjects'.$^{74}$ In the early years of its activities, private European traders and native agents had abused their trust and power in the 'collection of revenues' and in the 'conduct of the courts of justice'. But as a result of reforms introduced in 1769, Company servants had been brought under restraint, and are now 'worthy of more confidence than transient adventurers, ignorant and barbarous, from the Upper Asia'. ${ }^{75}$ 


\section{THE INTIMATE CONNEXION}

Having corrected abuses, and provided Hindu subjects with 'secure enjoyment of property', Grant inquired, 'does nothing further remain to be done?' He proceeds to identify in strikingly unambiguous arguments his vision for missionary work. Since the implementation of reform the Company has grown confident in its ability to maintain financial and political advantages. In areas, particularly Bengal, it is strong, and so long as Britain can retain superiority at sea, a challenge from European or Indian 'enemies' is unlikely. On the other hand,

Hindostan is the region of revolutions. A few more successful turns in Benares on the part of so inferior a chief as Cheyte Sing, would have put all Bengal in commotion. We ought also to remember how much the authority of a handful of strangers depends on opinion. To reduce the sources of prejudice against us, and to multiply impressions favourable to us, by assimilating our subjects to our mode of thinking, and by making them happy, and teaching them to understand and value the principles of the people who confer happiness upon them, may be some of the surest means of preserving the footing we have acquired. ${ }^{76}$

If such a project is to succeed, Grant continues, the 'state of society and manners among the people of Hindostan ... becomes in the first place a special object of attention'. He launches into an extended critique of previous studies, particularly those of travel writers and orientalists whom he sees as remote from the grim realities of Indian life: ${ }^{77}$

It has suited the views of some philosophers to represent that people as amicable and respectable; and a few late travellers have chosen rather to place some softer traits of their characters in an engaging light, than to give a just delineation of the whole.

For foreign residents and even the Indians themselves (presumably the only ones who can have real knowledge) the picture is very different:

Of the Bengalee then, it is true most generally that they are destitute, to a wonderful degree, of those qualities which are requisite to the security and comfort of society. They want truth, honesty, and good faith, in an extreme, of which European society furnishes no example.... Want of veracity especially, is so habitual, that if a man has truth to defend, he will hardly fail to recur to falsehood for its support. In matters of interest, the use of lying seems so natural, that it gives no provocation, it is treated as an excusable indulgence, $\ldots$ and the practice of cheating, pilfering, tricking and imposing, in the ordinary transactions of life are so common, that the Hindoos seem to regard them as they do natural evils, against which they will defend themselves as well as they can, but at which it will be idle to be angry. ${ }^{78}$

There follows a litany of traits. Cruelty, lack of benevolence and affection, gross laxity of behaviour and principle, indecency, licentiousness, 


\section{THE OTHER EMPIRE}

malevolence and animosity are seen by Grant as characteristic of the Bengali people, although he is careful to add that his wish was not to 'excite detestation, but to engage compassion, and make it apparent, that what speculation may have ascribed to physical and unchangeable causes, springs from moral sources capable of correction'.$^{79}$ Grant's engagement with Enlightenment humanism, however, was rather more complex than this rider suggests. Nowhere is this more apparent than in his discussion of progress. He concurs with the argument in Robertson's Historical Disquisition that the 'original inhabitants of Hindostan' never existed in a 'savage state', but he remained sceptical of the optimistic excesses of the stages theory of development. True, a people can reach the 'highest stages of refinement' through a long process of internal improvement, and in countries like India the 'ideas of men seem to ripen ... with a quickness analogous to the rapidity of their vegetation' ${ }^{\prime}{ }^{80}$ But progress has been mitigated by the debilitating influence of climate, despotic government, law, caste and mythology on the 'Hindoo character'. Under these circumstances the only cure of the darkness engulfing Indian society is 'the communication of our light and knowledge'. Of these, knowledge, as exemplified by English, printing, natural philosophy, agriculture and mechanics, is important, but 'undoubtedly the most important communication which the Hindoos could receive ... would be knowledge of our religion': ${ }^{\prime 1}$

It is not asserted, that such effects would be immediate, or universal; but admitting them to be progressive, and partial only, yet how great would the change be, and how happy at length for the outward prosperity and internal peace or society among the Hindoos! Men would be restored to the use of their reason; all the advantages of happy soil, climate, and situation, would be observed and improved; the comforts and conveniences of life would be increased; the cultivation of the mind, and rational intercourse, valued; the people would rise in the scale of human beings. ${ }^{82}$

In addition, and in conclusion, Grant declares:

[I]n communicating light, knowledge, and improvement, we shall obey the dictates of duty, of philanthropy, and of policy, we shall take the most rational means to remove inherent, great disorders, to attach the Hindoo people to ourselves, to ensure the safety of our possessions, to enhance continually their value to us, to raise a fair and desirable monument to the glory of this Country, and to encrease the happiness of the human race. ${ }^{83}$

Observations, like the Proposal, initially had a mixed reception. The taint of revolutionary fear from which Grant had attempted to distance himself proved too deep-seated. The king and Cornwallis thought that the scheme would interfere unduly with the established order in India. ${ }^{84}$ Wilberforce, on the other hand, while nervous at the prospect of aggressive 


\section{THE INTIMATE CONNEXION}

missionary activity of the sort set out in the Proposal, was reassured by the emphasis in Observations on education. His support heralded a commitment by the Clapham Sect to Indian reform that over time was to rival even outstrip - its interests in abolition and poverty. ${ }^{85}$ The Sect came to have only qualified success in realizing an ambition to have the Company sanction, indeed sponsor missionary activity, but it did establish the grounds upon which the case for British rule over the Indian people could be justified and maintained.

\section{The conversion of heathens}

There were, however, other influential currents of evangelical thought that in the short term were more decisive in promoting missionary activity. In the same year as Grant's Observations was written, the Baptist shoemaker William Carey published An Enquiry into the Obligations of Christians to use Means for the Conversion of Heathens. Modest in scope, it sought to demonstrate that in spite of the various attempts made since apostolic times to spread the gospel, a 'very considerable part of mankind are still involved in all the darkness of heathenism' ${ }^{86}$ These attempts continue, but they remain 'inconsiderable in comparison with what might be done if the whole body of Christians entered heartily into the spirit'. Carey counters the charge that missionary endeavour will meet with implacable resistance from the heathen by pointing to the example of traders, who in the pursuit of gain have shown it possible to 'insinuate themselves into the favour of the most barbarous clans, and uncultivated tribes'. And to those who object on the grounds that there are 'multitudes in our own nation ... who are as ignorant as the South-Sea savages', he declares that unlike those in foreign lands who have 'no Bible, no written language, no ministers, no good Civil government, nor any of those advantages which we have', we have the 'means of knowing the truth' ${ }^{87}$ Carey's vision, however, is an inclusive one. Quoting from Paul that there is 'no difference between the Jew and the Greek: for the same Lord over all, is rich unto all that call on him', he argues that of those that live in darkness, the majority are:

poor, barbarous, naked pagans, as destitute of civilization, as they are of true religion.... Barbarous as these poor heathens are, they appear to be capable of knowledge as we are, and in many places, at least, have discovered uncommon genius and tractableness. ${ }^{88}$

Missionary work, in contrast, is exclusive, for Carey concludes by proposing the formation of a missionary society amongst the particular Baptist denominations. This was not out of any desire to restrict such activity to one denomination, but 'in the present divided state of Christendom, it 


\section{THE OTHER EMPIRE}

would be more likely for good to be done by each denomination engaging separately in the work.... There is room enough for us all, without interfering with each other. ${ }^{\prime 89}$ Within a year the BMS was established; within a decade its mission at Serampur was busy in the work of preaching and translating the Bible into Indian languages..$^{90}$

Too little attention has been paid to these contrasts in missionary visions, and yet they are crucial to an understanding of how different denominations understood and approached subjects thought in need of salvation. Part of the problem derives from the notorious imprecision of the term evangelicalism in defining the broad range of socio-religious thought brought to bear on the perceived problems of the poor and nonChristian peoples. Used conventionally to embrace the broad spectrum of belief from evangelical Arminianism to high Calvinism, ${ }^{91}$ it masked important differences in attitudes toward predestination, millenarianism and rationalism leading to striking contrasts in approaches to material and spiritual pathologies.

The view that poverty and heathenism were the inevitable consequences of a spiritual want that could be cured only by evangelization shaped the thoughts and activities of succeeding generations of evangelicals working abroad and in the metropolis. ${ }^{92}$ Although the position of individuals in the continuum between pre- and postmillenarianism determined the emphases given to the role of spiritual versus material imperatives, it was generally the former that prevailed. Thus no matter how intense was sympathy for the plight of poor families, and how much individuals contributed to private charities, the solution to destitution was sought through redemption by aggressive evangelical activity.

The real significance of evangelicals derived from their ability to integrate theology with policy at a time of perceived crisis in the fabric of the empire brought about by the recognition of the presence at its heart of an endemic poor and of colonized peoples untouched by civilizing influences. For in spite of differences in emphasis, they shared a belief in the fundamentals of evangelicalism as a theology, namely, original sin, atonement though Christ's crucifixion, regeneration through faith, and attainment of holiness, around which were constructed powerful narratives that determined policies toward the colonial and metropolitan poor, and shaped the spiritual autobiographies of missionaries, and the lengthy commentaries on the state of moral and physical depravity they encountered.

These narratives had historical antecedents in the spiritual autobiographies of sixteenth- and seventeenth-century preachers. ${ }^{93}$ The human condition was a pilgrimage, the narrator an allegorical pilgrim who, following conversion, abandoned all to undertake an arduous spiritual journey through the world beset by the dangers of temptation and persecution in 
search of a promised land. There was no closure, however; the land proved beyond reach, condemning the pilgrim to ceaseless struggle. An authentic narrative of some remarkable and interesting particulars in the life of $\star \star \star \star \star \star \star \star \star$, written by John Newton in 1764, is representative of this genre. ${ }^{94}$ Newton was a captain of a slave ship who, during a severe storm, experienced a powerful conversion, subsequently abandoning his life of 'wickedness' to become one of the foremost evangelical preachers of the eighteenth century. In the Authentic narrative evangelical selfhood derived largely from this Pauline conversion. Newton's career at sea became a Christian experience, in which Bunyanesque images of storms, routes of navigation, shipwrecks and the dangers from enemy ships were used to convey a sense of the ways in which the immanent meaning in past misdeeds is revealed teleologically by ultimate meaning after conversion. Thus a theology was constructed around the familiar predestinarian narrative of salvation: calling, justification through faith, sanctification in good work, and final glorification. ${ }^{95}$

Certain homologies existed between the narratives of spiritual autobiography and travel writing. The emergence of a concern among eighteenth-century travellers with historical veracity achieved through uncorrupted use of scientific observation promoted among evangelicals those private virtues of honesty and integrity that underpinned diligent observation and recording of 'truth'. But while for the traveller personal validation is sought through the 'attainment of the reader's conviction', atonement in spiritual autobiography is achieved introspectively by the revelation of divine grace. ${ }^{96}$

Tensions in evangelical theology and policy reached some sort of resolution in 1813 with the introduction of the pious clause into the Company's charter. The complex chain of events leading up to this have been described elsewhere. ${ }^{97}$ Suffice it to say here that the shifting balance of forces among the Company, the British state, evangelical denominations and the Indian peoples have to be seen in the context of what often appeared as competing demands to secure imperial rule and to provide salvation to colonial subjects at a time of revolutionary and post-revolutionary struggle in France. But precisely how did evangelicals respond to events, in particular through changing perceptions of their relationships to India?

In the early days of British missionary activity Claudius Buchanan was appointed the Company chaplain to Bengal, and from this position he wrote influentially on the state of Christianity in India. He soon acquainted himself with the Serampur mission, and defended it against charges of Jacobinism levelled by many of his fellow Anglicans. Indeed, he helped with the work, and used his position to raise funds for translating the Bible into Indian languages. He was also instrumental in securing Carey's appointment as a lecturer in Bengali and Sanscrit at the newly 


\section{THE OTHER EMPIRE}

established Fort William College. By the time Buchanan began to write on India, however, relationships with the Baptist missionaries had become soured following his attempt to take control of their translation work. Mindful of the suggestion of Dr Porteus, the Bishop of London, that the Anglican church should control the activities of missionary work in India, and Wellesley's determination to eradicate the influence of French republicanism, ${ }^{98}$ Buchanan's Memoir on the Expediency of an Ecclesiastical Establishment for British India (1805) unsurprisingly owed rather more to Grant than Carey, even though many of the fears of 1793 had receded. 'Our extensive territorial triumph over our only formidable foe', he opened, 'seems to mark the present era, as that intended by Providence, for our taking into consideration the moral and religious state of our subjects in the East. ${ }^{99}$ His concern with the future of empire, however, stemmed less from the putative dangers attendant on attempts to convert Indians, than from the moral laxity of the British in India: ${ }^{100}$

The French revolution has imposed on us the duty of using new means for extending and establishing Christian principles. Our territorial possessions in the East have been nearly doubled in extent, and thence arises the duty of cherishing the religion and morals of the increased number of our countrymen who occupy these possessions; as well as promoting the civilization of our native subjects by every rational means. ${ }^{101}$

That the Memoir was written essentially to promote Anglican supremacy in India suggests that this responsibility was to be assumed by the established church in formal alliance with the Company. There followed a rather contradictory assessment of the prospects of reaching Indian subjects. On the one hand, Buchanan argues:

The natives of Hindostan are a Divided people. They have no common interest. To disseminate new principles among them is not difficult. They are less tenacious of opinion than of custom.... Our religion is therefore inculcated ... because its civilizing influence is certain and undeniable. We have seen that it has dispensed knowledge and happiness to every people, who have embraced it.... [I]t attaches the governed to their governors; and facilitates our intercourse with the natives. ${ }^{102}$

But this is mitigated with pessimism born out of an embryonic sense of racial separateness:

You will sometimes hear it said that the Hindoos are a mild and passive people. They have apathy rather than mildness, their hebetude of mind is perhaps their chief negative virtue. They are a race of men of weak bodily frame, and have a mind conformed to it, timid and abject in the extreme.... The European who has long been resident in India looks on the civilization of the Hindoos with a hopeless eye. Despairing, therefore, of intellectual or 
moral improvement, he is content with an obsequious spirit and manual service. $^{103}$

Buchanan concludes with a familiar list of the 'sanguinary rites' practised by Hindus including sati, swinging with hooks, drowning in the Ganges and sacrifice of children. Not content, in 'The Star in the East', a sermon preached at Bristol in 1809 for the benefit of the Society for Missions to Africa and the East, he attempts to undermine the positive features of the intellectual heritage of ancient India by rewriting the histories of Christianity and Hinduism. ${ }^{104}$ Drawing upon Wilford's The History of the Introduction of the Christian Religion into India, he proposes that Christianity appeared first in the East, thereby providing the inspiration for all religions. The presence in Vedic writings of doctrines including the trinity, incarnation, atonement and divine revelation proves this to be so. Our task in India, therefore, is to fulfil Christianity's destiny, not through the false creed of a Romish church sunk in the same darkness as Hinduism, but by the united efforts of Protestant evangelicals.

This task was hampered, however, by critical tensions at the heart of the evangelical vision that could not readily be resolved. First, uncertainty existed as to the precise means of realizing the Christian mission. Evangelicals embraced a teleological conception of progress. Buchanan, for example, posited a stages theory according to which the world develops historically through three eras - primitive Christianity, when Christ spread the gospel, the reformation, and finally the era of light, when the triumph of Christianity would inevitably result. ${ }^{105}$ This theory of progress, however, was tempered by a recognition of the need for active evangelical intervention, particularly among those who seemed to defy its logic. Second, the relationship between evangelical and imperial missions was a troubled one. As we have seen, there were elements within Anglican evangelicalism that openly stressed the benefits of Christianity to imperial rule. But Grant and Buchanan were hostile to much of Company policy; in turn, influential directors such as Major John Scott Waring and Thomas Twining, who claimed to represent the majority, viewed missionary activity as an undue interference in Indian culture, threatening the stability of the Indian empire. ${ }^{106}$ If anything, the relationships between frontline dissent - with a professed commitment to the reform and education of Indians - and the Company were even more strained. To mask these tensions, evangelical discourse hardened around a complex litany of Hindu cultural pathologies, descriptions of which were used to legitimate continued intervention. On the less than convincing precept that the 'untravelled writer ... enters into the discussion free from all the trammels of party and prejudice $^{\prime}{ }^{107}$ J.W. Cunningham chose to survey previous writings on Christianity in India. He selected quotations out of context from Jones, Orme, 
Verelst, Holwell and most especially Buchanan to demonstrate a putative consensus on the degenerate, enervated and treacherous nature of Hindus, on the basis of which he opines that 'although the physical and political powers of the Hindus would be increased by the introduction of Christianity, no increase of their power to inquire would necessarily take place'. ${ }^{108}$

In the course of the protracted and heated debates leading up to the renewal of the Company's charter in 1813, the most effective voices were those advocating strengthened missionary activity. Grant, Buchanan and Wilberforce wrote widely and lobbied tirelessly; missionary societies and their supporters organized a massive campaign of petitioning. ${ }^{109}$ The Charter Act passed through parliament by 89 votes to 36 . It declared:

$[W]$ hereas it is the Duty of the Country to promote the interests and happiness of the native inhabitants of the British dominions in India, ... such measures ought to be adopted as may tend to the introduction among them of useful knowledge, and of religious and moral improvement, and in furtherance of the above objects, sufficient facilities ought to be afforded by law to persons desirous of going to and remaining in India, for the purpose of accomplishing those benevolent designs so long as the authority of the local governments respecting the intercourse of Europeans with the interior of the country be preserved, and the principles of the British government on which the natives of India have hitherto relied for the free exercise of their religion be inviolably maintained. ${ }^{110}$

Hailed by evangelicals as a victory, the Act was in fact a skilful compromise. It established the authority of the Anglican church in India, but allowed missionaries to enter, albeit under continued close scrutiny. More significantly, the arguments used to define Christian obligations in India which were enshrined in the Act, and the nature of the peoples to whom these obligations applied, became unquestioned assumptions in British opinion. ${ }^{111}$ William Ward, a missionary at Serampur, undertook a comprehensive survey of Hindu society. Published in eight editions over 1811-22, his $A$ View of the History, Literature and Mythology of the Hindoos came to represent the tenor of this new consensus. 'It must have been to accomplish some very important moral change in the Eastern world', he opens, 'that so vast an empire as is comprized in British India' should have been placed under the 'dominion of one of the smallest kingdoms of the civilized world'. He proceeds:

This opinion, which is entertained unquestionably by every enlightened philanthropist, is greatly strengthened when we consider the long-degraded state of India, and of the immense and immensely populous regions around it; the moral enterprise of the age in which these countries have been given to us, and that Great Britain is the only country upon earth, from which the intel- 


\section{THE INTIMATE CONNEXION}

lectual and moral improvement of India could have been expected... To form a just conception of the state of darkness in which so many minds are involved as are comprized in the heathen population of India, a person has need to become an inhabitant of the country, that he may read and see the productions of these minds, and witness the effects of the institutions they have formed, as displayed in the manners, customs, and circumstances of the inhabitants. ${ }^{112}$

In the four volumes that followed, Ward detailed at inordinate length this 'state of darkness'. From the writings of Grant, researches of the orientalists and what 'the author has been able to collect and condense relative to the civil state of the Hindoos, the reader will be able to perceive something very superior to mere Savage life, or to brutal uncontrolled tyranny'. ${ }^{113}$ In the end, however, it is his exhaustive catalogue of pagan superstitions, idolatries and acts of extreme cruelty that prevailed to provide a vital source of information on Hindu worship.

Lata Mani has detected in the various editions a shift from a preoccupation with miscellany to a more rigorous and authoritative handling of information approximating to an ethnography. In the early editions Ward seemed to collect and randomly present curiosities of Hindu society, leaving the reader to synthesize the material and draw out its social and moral significance. The final edition, by contrast, contains claims that are 'confident, authoritative and totalizing'. ${ }^{114}$ This she sees as evidence of the consolidation of evangelical discourse in the years following 1813. There is something in these arguments. Over time Ward did rework the material. Any shift, however, has to be seen in the context of a hardening of evangelical discourse, and, more importantly, the emergence of a new mode of observation attendant on the continued sense of epistemological insecurity. For the shift evident in Ward was symptomatic of a more general crisis in the production of knowledge about India, in response to which travel and evangelical writings moved toward more totalizing perspectives.

\section{Notes}

1 For a more detailed account of Colquhoun's life and contribution, see my article 'Policing the poor: social inquiry and the discovery of the residuum', Rising East, 3:1, 1999, pp. 23-47.

2 [Patrick Colquhoun], A Treatise on the Police of the Metropolis, Explaining the Various Crimes ... which ... are felt as a Pressure upon the Community, and Suggesting Remedies for their Prevention. By a Magistrate, London, Dilly, 1795; A Treatise on the Commerce and Police of the River Thames: Containing an Historical Overview of the Trade of the Port of London; and Suggesting Means for Preventing the Depradations thereon, by a Legislative System of River Police, etc., London, Mawman, 1800; A Treatise on Indigence; Exhibiting a General View of the National Resources for Productive Labour; with Propositions for Ameliorating the Condition of the Poor, etc., London, Mawman, 1806. The last greatly expanded on arguments that originally appeared in a tract, significantly entitled The State of Indigence, and the Situation of the Casual 


\section{THE OTHER EMPIRE}

Poor in the Metropolis, Explained ... with Suggestions Shewing the Necessity ... of an Establishment of Pauper Police, Immediately Applicable to the Casual Poor, etc., London, Baldwin, 1799. These texts were all revised in several subsequent editions.

3 [Colquhoun], A Treatise on the Police, p. 44.

4 Colquhoun, $A$ Treatise on the Commerce and Police of the River Thames, p. 44.

5 Colquhoun, A Treatise on Indigence, pp. 7-8.

6 Ibid., p. 5.

7 Ibid., p. 36.

8 Ibid., p. 79.

9 See F. McLynn, Crime and Punishment in Eighteenth-Century England, London, Routledge, 1989, p. 8, and Tim Hitchcock, 'The publicity of poverty in early eighteenth-century London', in J.F. Merritt (ed.), Imagining Early Modern London. Perceptions and Portrayals of the City from Stowe to Strype, 1598-1720, Cambridge, Cambridge University Press, 2001.

10 [Colquhoun], A Treatise on the Police, p. 57.

11 Ibid., p. v.

12 Minutes of Evidence Taken before the Select Committee Appointed by the House of Commons to Inquire into the State of Mendicity and Vagrancy in the Metropolis and its Neighbourhood, London, Sherwood, Neely and Jones, 1815, p. 41.

13 Ibid., p. 78.

14 John Ralph, A Critical Review of the Public Buildings, Statues, and Ornaments, in and about London and Westminster, London, Wallis, 1783, p. 4.

15 The early days were precarious. In October 1798 the station was besieged by a riotous assembly of coal heavers who dispersed only after Colquhoun read the riot act and one of the police officers opened fire, fatally wounding, it was rumoured, one of the leaders.

16 J.R. Poynter, Society and Pauperism. English Ideas on Poor Relief, 1795-1834, London, Routledge, 1969, pp. 91-8.

17 Ibid., p. 97.

18 See the succinct and informative discussion in Boyd Hilton, The Age of Atonement. The Influence of Evangelicalism on Social and Economic Thought, 1795-1865, Oxford, Clarendon Press, 1988, pp. 98-100.

19 Report, I (1796), p. 12, cited in Poynter, Society and Pauperism, p. 92.

20 From the outset Portland, Secretary of State at the Home Department, had also been an enthusiastic supporter of Colquhoun's work.

21 Matthew Martin, Letter to the Right Hon. Lord Pelham, on the State of Mendicity in the Metropolis, London, Philanthropic Society, 1803, p. 3.

22 Poynter, Society and Pauperism, p. 98.

23 Speech of T.F. Buxton, Esq. At the Egyptian Hall, 26 November 1816 on the Subject of the Distress in Spitalfields, London, Phillips, 1816, p. 14.

24 Ibid., p. 17.

25 Minutes of Evidence Taken before the Select Committee ... into the State of Mendicity, p. iii.

26 Ibid., pp. iv, vi.

27 David Ludden, 'Orientalist empiricism: transformations of colonial knowledge', in Carol A. Breckenridge and Peter van der Veer (eds), Orientalism and the Postcolonial Predicament. Perspectives on South Asia, Philadelphia, University of Pennsylvania Press, 1993.

28 Matthew Edney, Mapping and Empire. The Geographical Construction of British India, 1765-1843, Chicago, University of Chicago Press, 1997, pp. 27-8.

29 Robertson was Principal of the University of Edinburgh and had written major histories of Scotland and America.

30 William Robertson, An Historical Disquisition concerning the Knowledge which the Ancients had of India, London, Cadell and Davies, 1817, pp. v-vi.

31 Ibid., p. 197.

32 Ibid., p. 286.

33 Peter J. Marshall (ed.), The British Discovery of Hinduism in the Eighteenth Century, 


\section{THE INTIMATE CONNEXION}

Cambridge, Cambridge University Press, 1970, p. 43.

34 See, for example, Ketaki Kushari Dyson, A Various Universe. A Study of the Journals and Memoirs of British Men and Women in the Indian Subcontinent, 1765-1856, Delhi, Oxford University Press, 1978; Charles Batten, Pleasurable Instruction. Form and Convention in Eighteenth-Century Travel Writing, Berkeley, University of California Press, 1978; Sara Mills, Discourses of Difference. An Analysis of Women's Travel Writing and Colonialism, London, Routledge, 1991; Dennis Porter, Haunted Journeys. Desire and Transgression in European Travel Writing, Princeton, University of Princeton Press, 1991; Mary Louise Pratt, Imperial Eyes. Travel Writing and Transculturation, London, Routledge, 1992; David Spurr, The Rhetoric of Empire. Colonial Discourse in Journalism, Travel Writing and Imperial Administration, Durham, Duke University Press, 1993; Tim Youngs, Travellers in Africa. British Travelogues 1850-1900, Manchester, Manchester University Press, 1994; Jyotsna Singh, Colonial Narratives/Cultural Dialogues. Discoveries of India in the Language of Colonialism, London, Routledge, 1996; David Miller and Peter Reill (eds), Visions of Empire. Voyages, Botany and Representations of Nature, Cambridge, Cambridge University Press, 1996; Indira Ghose, Women Travellers in Colonial India. The Power of the Female Gaze, Delhi, Oxford University Press, 1998; James Duncan and Derek Gregory (eds), Writes of Passage. Reading Travel Writing, London, Routledge, 1999; Tim Fulford and Peter Kitson (eds), Travels, Explorations and Empires, 1770-1835, 8 vols, London, Pickering and Chatto, 2002.

35 James Duncan and Derek Gregory, 'Introduction', in Duncan and Gregory (eds), Writes of Passage, pp. 5-6. Their argument that travel came also to embrace modernity because it was no longer a duty, but a pleasure in itself, increasingly undertaken as part of a 'quintessentially bourgeois experience', lacks conviction since it tends to privilege the eighteenth-century aristocratic grand tour as paradigmatic.

36 Henri Baudet, Paradise on Earth. Some Thoughts on European Images of NonEuropean Man, New Haven, Yale University Press, 1965, p. 55.

37 Dyson, A Various Universe, p. 19.

38 Ibid., p. 123. More recent scholarship has tended to substantiate this prescient but undeveloped thesis - see, for example, Tim Fulford and Peter Kitson (eds), Romanticism and Colonialism. Writing and Empire, 1780-1830, Cambridge, Cambridge University Press, 1998.

39 William Hodges, Travels in India during the Years 1780, 1781, 1782, ↔) 1783, London, Edwards, 1793, pp. iii-iv.

40 Ibid., p. 2.

41 James Duncan, 'Dis-orientation: on the shock of the familiar in a far-away place', in Duncan and Gregory (eds), Writes of Passage.

42 George Forster, A Journey from Bengal to England, through the Northern Part of India, Kashmire, Afghanistan, and Persia, and into Russia, by the Caspian Sea, London, Faulder, 1798, p. x.

43 Ibid., p. 96.

44 Ibid., pp. 286, 291.

45 Ibid., p. 295.

46 Dyson, A Various Universe, p. 32.

47 Ghose, Women Travellers in Colonial India, p. 158.

48 Jemima Kindersley, Letters from the Island of Teneriffe, Brazil, the Cape of Good Hope, and the East Indies, London, 1777, pp. 72-3.

49 Ibid., p. 193.

50 Ibid., p. 180.

51 Ibid., p. 182.

52 Thomas Williamson, The East India Vade-Mecum; or, Complete Guide to Gentlemen intended for the Civil, Military, or Naval Service of the Hon. East India Company, London, Black, Parry and Kingsbury, 1810, p. v.

53 Ibid., pp. 193-4.

54 Ibid., pp. 200-1.

55 Kate Teltscher, India Inscribed. European and British Writings on India, 1600-1800, 


\section{THE OTHER EMPIRE}

Delhi, Oxford University Press, 1997, pp. 146-50.

56 Williamson, The East India Vade-Mecum, p. 398.

57 Teltscher, India Inscribed, p. 74.

58 See, for example, D.W. Bebbington, Evangelicalism in Modern Britain. A History from the 1730s to the 1980s, London, Unwin Hyman, 1989; Brian Stanley, The Bible and the Flag. Protestant Missions and British Imperialism in the Nineteenth and Twentieth Centuries, Leicester, Apollos, 1990; M.A. Noll, D.W. Bebbington and G.A. Rawlyk (eds), Evangelicalism. Comparative Studies of Popular Protestantism in North America, the British Isles and Beyond, 1700-1990, New York, Oxford University Press, 1994; John Woolfe (ed.), Evangelical Faith and Public Zeal. Evangelicals and Society in Britain, 1780-1980, London, SPCK, 1995; Susan Thorne, Congregational Missions and the Making of an Imperial Culture in Nineteenth-Century England, Stanford, Stanford University Press, 1999.

59 Thorne, Congregational Missions, Chapter 2.

60 Andrew Porter, 'Religion, missionary enthusiasm, and empire', in Andrew Porter (ed.), The Oxford History of the British Empire. Vol. III. The Nineteenth Century, Oxford, Oxford University Press, 1999.

61 Thorne, Congregational Missions, pp. 26-36.

62 See above, pp. 107-9.

63 Here Thorne's attempt to identify distinctions between the poor and the colonized is misplaced (Congregational Missions, p. 34). Her emphasis on the poor law and philanthropy leads to a neglect of other ways in which the poor were represented, most particularly their criminalization within a metropolitan context. And the emergence of more severe cultural - later, racial - coding was not the product of missionary endeavour. Rather missionaries had a particular take on, and were busy in promoting, conceptions of the colonized other that were being transformed by more general notions of progress.

64 Joseph White, Sermons Preached before the University of Oxford, in the Year 1784, London, Robinson, 1785.

65 The standard biographies are Henry Morris, The Life of Charles Grant, London, Murray, 1904, and Ainslie Embree, Charles Grant and British Rule in India, London, Allen and Unwin, 1962.

66 Embree, Charles Grant, p. 51. The idea of a conversion was originally put forward by Morris, but qualified by Embree on the grounds that it did not seem to exhibit the characteristic features of conversion described in evangelical narratives.

67 Ibid., p. 65.

68 Letter from Charles Grant to Thomas Raikes, 23 October 1784, cited in Morris, The Life of Charles Grant, pp. 96-7.

69 No copy of this document has survived. The synopsis that follows is taken from a covering letter dated 17 September 1787, sent by Grant to Wilberforce with a copy of the Proposal (Morris, The Life of Charles Grant, pp. 108-14).

70 Ibid., pp. 110-12.

71 Embree, Charles Grant, p. 119.

72 It was presented formally to the Board of Directors in 1797, and made generally available when published as a contribution to the debates on renewal of the charter in 1813 (ibid., pp. 141-2).

73 Charles Grant, Observations on the State of Society among the Asiatic Subjects of Great Britain, particularly with reference to Morals; and on the Means of improving it. Written chiefly in the Year 1792, Parliamentary Papers, 1813, X, p. 5.

74 Ibid., pp. 2, 5.

75 Ibid., p. 13.

76 Ibid., pp. 23-4.

77 Grant read selectively. Much of his evidence was based on quotations excavated from the archives of the Company, supplemented by Bernier's Voyages, Luke Scrafton's Reflections on the Government of Indostan, Holwell's Historical Events, Verelst's View of the English Government in Bengal, the parliamentary proceedings against Hastings, and John Shore's Asiatic Researches. Early travel accounts by the likes of 


\section{THE INTIMATE CONNEXION}

Roe, Hamilton, Baldaeus and Tavernier were omitted for the sake of brevity.

78 Grant, Observations, p. 26.

79 Ibid., p. 39.

80 Ibid., p. 75.

81 Ibid., p. 79.

82 Ibid., p. 80.

83 Ibid., p. 112.

84 Penelope Carson, 'Soldiers of Christ: evangelicals and India, 1784-1833', unpublished PhD thesis, University of London, 1988.

85 Wilberforce was famously to declare to parliament in 1813: 'It was formerly my task to plead the cause of people whose woes affected every heart, who were finally rescued from the situation in which they groaned by the abolition of the slave trade. That cause was doubtless the cause of suffering humanity: but I declare that, even if we exclude the consideration of religion, humanity appears to me to be still more concerned in the cause I am now pleading, than in that of which I was formerly the advocate.'

86 William Carey, An Enquiry into the Obligations of Christians to use Means for the Conversion of Heathens in which the Religious State of the different Nations of the World, the Success of former Undertakings, and the Practicability of further Undertakings, are considered, Leicester, 1792, p. 5. Carey estimated that of the 731 million people in the world, 420 million were still in pagan darkness.

87 Ibid., p. 12.

88 Ibid., pp. 63-4.

89 Ibid., p. 84.

90 For an interesting account of this early work, particularly with regard to street preaching, see Lata Mani, Contentious Traditions. The Debate on Sati in Colonial India, Berkeley, University of California Press, 1998.

91 The distinct theological positions evident in evangelicalism are usefully summarized in D.B. Hindmarsh, John Newton and the English Evangelical Tradition Between the Conversions of Wesley and Wilberforce, Oxford, Clarendon Press, 1996, pp. 124-5.

92 Heartened by early work in India, and to an extent using it as a model for further action, the BMS was to lead missionary endeavour in the Caribbean some twenty years later. It too was faced with fierce opposition from colonial interests, most notably the planters. On a wave of anti-slavery sentiment early in the 1820 s, however, it was able to consolidate its activities in Jamaica. Caribbeans, like Indians, were seen to be lost in dark heathenism and savagery, but if anything even further down in the evolutionary chain. For reasons that have not been fully explored, striking contrasts existed in the outcomes of missionary endeavour. While in India evangelicals had little success in converting the indigenous population, in Jamaica thousands were converted in the period leading up to the 1840s. Proportionately this represented a far greater intervention (see the recent meticulous study by Catherine Hall, Civilising Subjects. Metropole and Colony in the English Imagination, 1830-1867, London, Polity, 2002).

93 I. Rivers, 'Strangers and pilgrims: sources and patterns of Methodist narrative', in J.C. Hilson, M.M.B. Jones and J.R. Watson (eds), Augustan Worlds, Leicester, Leicester University Press, 1978; P. Caldwell, The Puritan Conversion Narrative, Cambridge, Cambridge University Press, 1986; Hindmarsh, John Newton and the English Evangelical Tradition.

94 The text has been skilfully read by Hindmarsh, John Newton and the Evangelical Tradition.

95 Ibid., p. 42.

96 Michael McKeon, The Origins of the English Novel, London, Radius, 1988, p. 104.

97 See, for example, Embree, Charles Grant; Eli Potts, British Baptist Missionaries in India, 1793-1858, Cambridge, Cambridge University Press, 1967; Carson, 'Soldiers of Christ'; Karen Chancey, 'The Star in the East: the controversy over Christian missions to India, 1805-1813', Historian, Spring, 1998.

98 See the retrospective account in Claudius Buchanan, Christian Researches in Asia 


\section{THE OTHER EMPIRE}

(1812), reproduced in The Works of the Rev. Claudius Buchanan, New York, Whiting and Watson, 1812. Christian Researches was based on Buchanan's travels around India during which he recorded detailed observations on the barbarities of Hindu customs. It was published in nine editions over two years, becoming the most widely read of his numerous publications.

99 Claudius Buchanan, Memoir of the Expediency of an Ecclesiastical Establishment for British India (1805), reproduced in The Works of the Rev. Claudius Buchanan, p. 188.

100 Buchanan was the first to point to the moral ambiguities of the pilgrim tax - a levy, as far as he was concerned, to raise revenue from such barbaric practices as Jagganath sacrifice.

101 Ibid., p. 201.

102 Ibid., p. 205.

103 Ibid., pp. 209, 211

104 Claudius Buchanan, The Star in the East; a Sermon preached in the Parish Church of St. James, Bristol, New York, Williams and Whiting, 1809.

105 George Bearce, British Attitudes towards India, 1784-1858, Oxford, Oxford University Press, 1961, p. 80.

106 See, for example, John Scott Waring, Observations on the Present State of the East India Company, London, 1808; Remarks Preached before the University of Oxford, London, 1808; Remarks on Rev. Dr. Buchanan's Christian Researches in Asia, London, Ridgway, 1812; Thomas Twining, A Letter to the Chairman of the East India Company. On the Danger of Interfering in the Religious Opinions of the Natives of India, London, 1807.

107 J.W. Cunningham, Christianity in India. An essay on the Duty, Means, and Consequences, of introducing the Christian Religion among the Native Inhabitants of the British Dominions in the East, London, Hatchard, 1808, p. xi.

108 Ibid., p. 188.

109 Some 897 petitions were presented to parliament in the months leading up to the vote, 281 of which resulted from the efforts of 'friends and supporters' of the Baptist mission in India. To date, this was the largest number presented on any issue, and did much to bring India into the popular metropolitan imagination (Carson, 'Soldiers of Christ', p. 301; Mani, Contentious Traditions, p. 121).

110 East India Company Charter Act (1813), 53 Geo. III cap. 155, section 33.

111 Embree, Charles Grant, p. 155.

112 William Ward, A View of the History, Literature and Mythology of the Hindoos, 4 vols, London, British Missionary Society, 1817-20, Vol. I, p. xxiii.

113 Ibid., Vol. III, pp. vii-viii.

114 Mani, Contentious Traditions, p. 128. 